\title{
PERILAKU ALIENASI DI SMP NEGERI 6 MAKALE
}

\author{
Yorinda Tammu ${ }^{1}$, A. Octamaya Tenri Awaru ${ }^{2}$ \\ ${ }^{1,2}$ Program Studi Pendidikan Sosiologi, Fakultas Ilmu Sosial, Universitas Negeri Makassar \\ yorindtammu@gmail.com ${ }^{1}$, a.octamaya @unm.ac.id ${ }^{2}$
}

\begin{abstract}
ABSTRAK
Alienasi adalah suatu kondisi ketika manusia dijauhkan atau menjauhkan diri dari sesuatu, sesama manusia, alam, budaya, tuhan, atau bahkan dirinya sendiri. Siswa teralieansi yaitu siswa merasakan tertekan dalam proses pembelajaran dan juga tidak memiliki teman di dalam kelas karena masing-masing menganggap teman sebagai saingan atau musuhnya. Penelitian ini bertujuan untuk mengetahui: 1) Bentukbentuk alienasi di SMP Negeri 6 Makale; dan 2) Dampak Alienasi bagi siswa yang teralienasi. Jenis penelitian adalah kualitatif deskriptif. Informan penelitian dipiligh dengan menggunakan tehnik purposive sampling. Jumlah informan sebanyak 12 orang. Teknik pengumpulan data yang digunakan yaitu observasi, wawancara dan dokumentasi. Data yang diperoleh kemudian di analisis melalui tiga tahap yaitu reduksi data, penyajian data dan penarikan kesimpulan. Teknik pengabsahan data dengan menggunakan member check Hasil penelitian ini menunjukkan bahwa; 1. Bentuk alienasi di SMP Negeri 6 Makale adalah; a) ketidakberdayaan (powerlessness), b) keterasingan diri (self estrangement), c) tidak ada norma (normlessnes) dan d) terisolasi secara sosial (social isolation), 2. Dampak alienasi yang dialami siswa pada SMP Negeri 6 Makale adalah a) dampak negatif meliputi; siswa merasakan tertekan dalam belajar, kehilangan semangat belajarnya, merasa dibatasi dalam hal bermain. b) dampak positif yaitu siswa termotivasi untuk lebih maju dengan mengubah cara belajarnya untuk mendapatkan nilai yang bagus.
\end{abstract}

Kata kunci: Alienasi, Sekolah, Siswa

\section{ABSTRACT}

Alienation is a condition when humans are kept away or away from something, fellow human beings, nature, culture, god, or even himself. Alienated students are students feel depressed in the learning process and also do not have friends in the class because each considers friends as rivals or enemies. This study aims to determine: 1) Forms of alienation in SMP Negeri 6 Makale; and 2) Impact of Alienation for alienated students. This type of research is descriptive qualitative. Research informants are selected using purposive sampling techniques. There were 12 informants. Data collection techniques used are observation, interviews and documentation. The data obtained were then analyzed through three stages, namely data reduction, data presentation and drawing conclusions. Data validation technique using member check The results of this study indicate that; 1. Forms of alienation in Makale 6 Public Middle School are; a) powerlessness, $b$ ) self estrangement, c) normlessnes and d) social isolation, 2. The impact of alienation experienced by students at SMP Negeri 6 Makale is a) negative impacts include; students feel pressured in learning, lose their enthusiasm for learning, feel restricted in terms of play. b) positive impact that students are motivated to move forward by changing the way they learn to get good grades.

Keywords: Alienation, School, Student

\section{PENDAHULUAN}

Pendidikan merupakan jalur utama yang harus ditempuh manusia untuk ikut dalam perkembangan zaman untuk membekali generasi baru dengan pengetahuan dan keterampilan yang dibutuhkan. Pendidikan adalah usaha yang dilakukan untuk memperbaiki sesuatu yang dianggap kurang baik menjadi lebih baik, selain itu pendidikan juga merupakan salah satu cara untuk mengoptimalkan perekembangan dan potensi individu.

Setiap individu memang selalu berharap bahwa dirinya mampu berkembang secara optimal dan untuk menjadi individu yang lebih baik di dalam sebuah masyarakat. Dalam proses pembelajaran tugas seorang pendidik bukan hanya bertanggung jawab mentransfer 
pengetahuan kepada siswa melainkan seorang pendidik harus mampu mendidik untuk mengoptimalkan potensi yang dimiliki anak didik sehingga menjadi anak yang cerdas dan berbudi pekerti luhur. Salah satu karakter yang harus ditanamkan pada diri peserta didik adalah kemampuan untuk menghargai diri sendiri dan orang lain . Menghargai diri sendiri dan menghargai orang lain tidak muncul begitu saja dalam diri seseorang semua itu membutuhkan sebuah proses dan kesadaran individu itu sendiri untuk bisa diakui dalam sebuah lingkungan, karena setiap individu untuk merasa lebih kompeten dan berguna mereka membutuhkan pengakuan dari orang lain atas nilai dan kompetensi yang dimiliki (Ashar \& Awaru, 2017).

Salah satu persoalan yang di hadapi dalam proses pembelajaran adalah terlalu banyaknya materi yang harus dikuasi oleh siswa yang menyebabkan tidak semua materi terserap dengan baik. Disamping itu permasalahan muncul akibat masih banyak guru kurang professional dalam mengajar, mereka masih kurang terlatih dalam menggunakan metode pembelajaran yang lebih menarik sehingga siswa tidak akan merasa bosan dan tertekan dlam belajar.

Hambatan-hambatan atau problematika yang ditemukan pada para pendidik kemudian berdampak pula pada para siswa. Masalah itu kemudian hadir dan mempengaruhi kesenangan maupun kenyamanan dalam dunia belajar siswa ketika mengikuti proses belajar (Fahyuni \& Istikomah, 2016). Siswa kemudian dituntut untuk menggali dan atau mencari informasi atau materi pembelajaran sendiri dan menemukan sendiri jawaban ketika ada latihan atau ulangan yang terdapat dalam buku ajar tersebut. Siswa dituntut seperti esin penggerak Sedangkan guru sebagai fasilitator yang mana akan memeberi penegasan atau penjelasan ketika siswa atau pelajar tersebut mengalami kesulitan.

Kondisi ini berpengaruh terhadap kenyamanan siswa dalam belajar. Siswa yang terbiasa belajar dengan menjadikan guru sebagai pusat informasi menjadi kurang nyaman dengan pembelajaran tersebut. Sehingga pada akhirya menyebabkan siswa kurang termotivasi dalam belajar atau dengan kata lain siswa merasa teralienasi dalam proses belajar tersebut. Padahal seharusnya sebuah proses pembelajaran dapat dan harus membuat siswa lebih manusiawi, mengingat pendidikan merupakan salah satu tolak ukur kemajuan suatu negeri. Peserta didik atau yang akrab disebut siswa kebanyakan dari mereka telah kehilangan kesenangan untuk melakukan kegiatan belajar, hal ini kemudian berakibat pada hilangnya semangat dari mereka untuk mengikuti pelajaran dikelas.

Hal demikian dipengaruhi oleh terjadinya proses pengasingan atau yang disebut dengan alienasi dalam dunia pendidikan terhadap diri para pelajar, dimana harusnya proses belajar merupakan proses yang penuh makna dan merupakan sebuah proses yang menyenangkan dan membuat yang terlibat di dalamnya dalam hal ini peserta didik dapat menemukan dirinya sendiri bukan karena sebuah paksaan atau tekanan dari orang lain (Hascher \& Hagenauer, 2010). Akan tetapi hal yang kemudian terjadi dalam dunia pendidikan saat ini adalah bahwa proses belajar bagi siswa atau peserta didik merupakan beban berat yang harus dipikul oleh mereka, karena mereka hanya berpatok kepada nilai saja. Nilai yang kemudian menjadi tolok ukur bagi siwa untuk mencapainya dengan semaksimal mungkin.

Alienasi atau keterasingan merupakan teori Karl Marx yang lebih familiar dikalangan pebisnis atau bidang ekonomi, Karena sesungguhnya teori ini memang merupakan teori ekonomi (Syukur, 2018). Selain itu peran Karl Marx juga sangat berpengaruh terhadap cara berpikir tentang pendidikan dan masyarakat. Marx menyebut keterasingan sebagai proses historis dimana manusia semakin terasing dari alam, dari 


\section{Jurnal Sosialisasi \\ Jurnal Hasil Pemikiran, Penelitian, dan Pengembangan \\ Keilmuan Sosiologi Pendidikan \\ Vol 7, Nomor 2, Juli 2020}

produk aktivitas mereka, baik secara nature maupun secara nurture. Tujuan dari penelitian ini adalah untuk menguraikan Bentuk-bentuk alienasi di SMP Negeri 6 Makale; dan dampak alienasi bagi siswa yang teralienasi.

\section{METODE PENELITIAN}

Berdasarkan rumusan masalah dan tujuan penelitian yang telah ditetapkan maka jenis maka jenis penenlitian yang digubakan dalam penenlitian ini yaitu jenis kualitatif dengan pendekatan deskriptif (Moleong, 2014). Lokasi dalam penenlitian ini adalah SMP Negeri 6 Makale. Teknik penentuan informan dipilih secara purposive sampling dengan jumlah informan 12 orang dengan kriteria yaitu siswa yang sering tidak mengerjakan tugas, siswa yang sering menyendiri dan siswa yang tidak suka dengan mata pelajaran tertentu. Sumber data dalam penenlitian ini yaitu data primer dan data sekunder . teknik pengumpulan data yang digunakan yaitu observasi, wawancara dan dokumentasi. Data yang diperoleh dalam penenlitian ini kemudian dianalisis dengan tahapan mereduksi data, menyajikan data dan penarikan kesimpulan (Miles \& Huberman, 1994). Teknik keabsahan data menggunakan member check.

\section{HASIL PENELITIAN DAN PEMBAHASAN}

\section{Bentuk-Bentuk Alienasi Siswa Di SMP Negeri 6 Makale}

Pembahasan ini mengenai bentuk-bentuk alienasi yang ditemukan penulis pada SMP Negeri 6 Makale dimana penulis melihat bentuk alienasi yang pertama yaitu: ketidakberdayaan (powerlessness), karena ada beberapa siswa yang merasa terpaksa dalam aktivitas belajarnya sehingga siswa merasa asing dalam melakukan aktivitasnya sendiri pada saat terjadi proses belajar dalam kelas, dimana siswa tersebut tidak menyukai mata pelajaran karena mata pelajaran tersebut dirasa sulit dan tidak sesuai dengan kemampuan dan keinginan siswa, serta siswa begitu terbebani dengan tugas yang diberikan kepada mereka, karena selain bersekolah mereka juga memiliki tanggung jawab lain di rumah seperti menyelesaikan pekerjaan rumah baik itu yang dikerjakan di rumah maupun di kebun.

Kedua keterasingan diri (Self-estrangement) karena banyak siswa yang merasa terpaksa dalam aktivitas belajarnya sehingga siswa merasa asing dan merasa tidak berdaya dalam melakukan aktivitasnya sendiri pada saat terjadi proses belajar mengajar dalam kelas, dimana sebagian siswa yang merasa sangat terpaksa mengerjakan tugas mereka karena hal demikian adalah tanggung jawab yang mereka harus kerjakan meskipun sebenarnya mereka tidak ingin, keterasingan diri membuat mereka menjadi berbeda dari dirinya karena melakukan sesuatu bukan atas keinginannya sendiri. Ketiga yaitu tidak ada norma (Normlessness), siswa-siswa yang mengalami hal demikian mereka sepertinya mengabaikan akan aturan-aturan yang berlaku di sekolah, hal tersebut mungkin dipicuh oleh kurangnya perhatian dari guru yang mengakibatkan mereka bertindak demikian, karena merasa kurang diperhatikan oleh guru.

Keempat terisolasi secara sosial (social isolation), berdasarkan hasil penelitian dapat dinyatakan bahwa siswa teralienasi oleh teman yang disebabkan oleh teman lainnya yang melihat dari kondisi fisik, karakter dan latar belakang dari siswa, selain itu siswa juga saling memperebutkan kompetisi atau belomba-lomba untuk menjadi juara kelas, karena siswa sebelum menginjak lingkungan sekolah sudah terlebih dahulu dibekali oleh orang tua untuk mendapatkan ranking satu agar menjadi yang terbaik dari semuanya. Akibatnya 


\section{Jurnal Sosialisasi \\ Jurnal Hasil Pemikiran, Penelitian, dan Pengembangan \\ Keilmuan Sosiologi Pendidikan \\ Vol 7, Somor 2, Juli 2020}

persaingan tersebut mengakibatkan siswa melihat teman didalam kelas itu sebagai saingannya dan bukan sebagai mitra belajarnya.

Berdasarkan teori Karl Marx buruh teralienasi dari aktivitas kerjanya, idealnya orang bekerja bukan hanya untuk memenenuhi kebutuhannya, melainkan juga untuk mengembangkan potensi yang dimilikinya dalam sistem dalam kapitalisme, buruh ternyata tidak memiliki cara untuk mengekpresikan potensinya, mereka hanya menunaikan tugas dan kewajiban dan perintah pemilik modal. (2) buruh teralienasi dari produk yang dihasilkan, buruh adalah bagian terpenting dari proses produksi, tetapi apa yang diproduksi dan bagaimana memproduksinya adalah atas keinginan para kapitalis. (3) buruh teralienasi dari buruh lain, kapitalisme industrial telah mendorong suasana kerja kooperatif menjadi kompetitif dalam hal demikian para buruh tidak lebih hanya onggokan pekerja yang tidak memiliki kesempatan untuk menjalin hubungan kebersamaan dalam sepenanggungan. (4) buruh teralienasi dari potensi yang dimiliki, kapitalisme industrial telah mengubah manusia menjadi alat untuk memproduksi barang. (Ja'far Shodiq, 2018), (Dinillah, 2018)

Selain dari teori Marx teori alienasi juga dikemukakan oleh Erich Fromm bahwa alienasi adalah keadaan dimana manusia mengalami keterasingan dengan aktivitas produksi, hasil produksi, diri sendiri dan lingkungan (Kumari, 2016). Berdasarkan teori Melvin Seeman tentang manusia alienasi yang disebutnya ketidakberdayaan (powerlessness) sudah sesuai dengan hasil penelitian dimana dalam hal mata pelajaran dikarenakan ada beberapa siswa yang merasa terpaksa dalam aktivitas belajarnya sehingga siswa merasa asing dalam melakukan aktivitasnya sendiri pada saat terjadi proses belajar dalam kelas, dimana siswa tersebut tidak menyukai mata pelajaran karena mata pelajaran tersebut dirasa sulit dan tidak sesuai dengan kemampuan dan keinginan siswa.

Seperti yang diungkapkan oleh Marx bahwa alienasi terdiri dari empat komponen yakni "Buruh teralienasi dari aktivitas kerjanya, buruh teralienasi dari produk yang dihasilkan, buruh teralienasi dari buruh lain, dan buruh teralienasi dari potensi yang dimiliki (Jones, 2010). Dari hasil penelitian yang dilakukan oleh penulis, bentuk alienasi yang pertama yakni ketidakberdayaan (powerlessness) dikarenakan ada beberapa siswa yang merasa terpaksa dalam aktivitas belajarnya disebabkan ketidaksukaan siswa tersebut terhadap sebagian mata pelajarannya tetapi tidak berdaya untuk tidak mengikutinya sehingga hal tersebut membuat siswa merasa asing dengan aktivitasnya sendiri di dalam kelas. Hasilnya adalah siswa teralienasi dari dirinya sendiri, karena mereka terkurng dalam ruang kelas yang membosankan dengan mata pelajaran yang mereka tidak sukai.

Berdasarkan teori Melvin Seeman yang kedua yaitu, keterasingan diri (Selfesgtrangemenet) (Widodo, 2000), (Marandika, 2018) sudah sesuai dengan hasil penelitian karena hasil penelitian ini menunjukkan bahwa banyak siswa yang merasa terpaksa dalam aktivitas belajarnya sehingga siswa merasa asing dan merasa tidak berdaya dalam melakukan aktivitasnya sendiri pada saat terjadi proses belajar mengajar dalam kelas, dimana sebagian siswa yang merasa sangat terpaksa mengerjakan tugas mereka karena hal demikian adalah tanggung jawab yang mereka harus kerjakan meskipun sebenarnya mereka tidak ingin.

Ketiga yaitu , tidak ada norma (normlessness) sudah sesuai dengan hasil penelitian dimana hasil penelitian ini menunjukkan bahwa ada aturan yang berlaku dalam sekolah akan tetapi aturan tersebut tidak berlaku bagi mereka yang disebut teralienasi, mereka mengabaikan norma yang ada, hal demikian menyebabkan munculnya penyimpangan yang dilakukan oleh sebagian siswa. 
Alienasi dalam hal terisolasi secara sosial (social isolation) sudah sesuai dengan hasil penelitian dimana siswa merasa bahwa teman disekitarnya atau dalam kelasnya merupakan lawan dan bukan sebagai teman belajarnya (SMAN \& ISKANDAR, 2019). Ruangan kelas harusnya menjadi tempat untuk mendapatkan banyak teman akan tetapi berbeda dengan yang dialami oleh beberapa siswa di SMP Negeri 6 Makale keterasingan yang dialami mereka disebabkan oleh karena adanya rasa keinginan untuk menjadi juara dalam kelas, mempertahankan peringkat mereka merupakan hal yang harus bagi mereka sehingga hal tersebut menjadikan teman dalam kelas sebagai saingan dan bukan sebagai teman belajar, hal tersebut menimbulkan rasa egoisme bagi masing-masing siswa karena rasa takut untuk dikalahkan oleh teman yang lainnya dan berusaha untuk tetap menjadi juara kelas.

Selain itu hal lain yang membuat sebagian siswa terasingkan itu dikarenakan kondisi fisik, karakter serta latar belakang yang berbeda membuat sebagian siswa terasingkan dari temannya, hal tersebut membuat beberapa siswa tersudutkan dan merasa kesepian dan akhirnya mereka teralienasi. Penelitian ini hampir sama dengan penelitian yang telah dilakukan oleh (Ja'far Shodiq, 2018) yang menunjukkan ketidaknyamanan lingkungan sekolah dikarenakan banyak faktor yaitu beberapa siswa yang merasa tidak nyaman di sekolah dikarenakan beberapa faktor yaitu guru yang galak, pelajaran yang meraka tidak sukai, persaingan antar siswa memperebutkan ranking.

\section{Dampak Alienasi Di SMP Negeri 6 Makale}

Ketika seseorang atau siswa mengalami alienasi dalam kehidupannya tentu hal itu akan membawah sebuah dampak, tentunya dampak itu merupakan dampak negatif dan dampak positif. Pada tahap ini penulis akan membahas pertama dampak negatif dimana penulis menemukan tiga dampak negatif alienasi yang dialami oleh beberapa siswa di SMP Negeri 6 Makale, yakni yang pertama yaitu siswa yang merasakan tertekan dalam belajar, siswa yang semangat belajarnya hilang dan siswa yang waktu bermainya kurang atau merasa dibatasi.

Dampak negatif yang pertama yaitu berdasarkan hasil wawancara diatas dapat dinyatakan bahwa dampak negatif dari alienasi adalah siswa merasa tertekan yang disebabkan oleh mata pelajaran dan tugas-tugas yang diberikan guru, dalam hal ini aktivitas belajar siswa terjadi tidak sesuai keinginan mereka, dalam proses pemberian mata pelajaran siswa mau tidak mau, suka tidak suka harus menyelesaikan target materi pelajaran untuk mendapatkan nilai bagus.

Dampak negatif yang kedua yaitu berdasarkan hasil wawancara diatas maka dapat dinyatakan bahwa dampak negatif lainnya dari alienasi adalah siswa tidak semangat dalam proses belajar dikarenakan metode atau cara mengajar guru yang kurang baik, terdapat beberapa siswa yang tidak menyukai cara mengajar guru yang kebanyakan hanya menyuruh mencatat tanpa menjelaskan terlebih dahulu pelajarannya. Hal tersebut membuat siswa jadi tidak semangat dalam belajar dan terkadang melakukan hal yang tidak ada kaitannya dengan mata pelajaran yang sedang dipelajari seperti menggambar dan tidur di dalam kelas.

Dampak negatif yang ketiga yaitu berdasarkan hasil wawancara di atas dapat dinyatakan bahwa dampak negatif berikutnya dari alienasi adalah siswa merasa tidak bebas atau dibatasi dalam hal bermain atau mencari sesuatu yang mereka inginkan, terkadang guru tidak memperdulikan potensi siswa dimana, siswa yang terkurung lama di kelas mentalnya tidak berkembang baik karena kurangnya sosialisasi dengan orang lain dan lingkungannya karena dipaksa belajar agar memenuhi target orang tua dan guru untuk 
berprestasi, banyak dari siswa tersebut menginginkan waktu untuk bersantai dan bermain tanpa harus mengerjakan tugas tetapi hal itu sangat susah untuk mereka lakukan yang membuat mereka merasakan dibatasi kebebasannya karena harus belajar dan mengerjakan tugas (Trusty \& Dooley-Dickey, 1993).

Kedua dampak positif selain dampak negatif alienasi juga memiliki dampak positif yakni penulis menemukan bahwa dampak positif dari alienasi adalah memberikan motivasi lebih kepada siswa untuk mendapatkan nilai dan prestasi yang baik sebagai bukti kepada temannya bahwa dia juga mampu atau bisa mendapatkan nilai yang bagus walaupun diajuhi dan tidak disukai oleh teman-temannya (Nutbeam, Smith, Moore, \& Bauman, 1993). Kondisi siswa yang terasingkan dari temannya tidak memadamkan semangatnya, justru perlakuan temannya yang menjauhi serta tidak ingin bergaul dengannya membuat mereka bersemangat untuk menunjukkan kemampuannya bersaing didalam kelas, dan juga untuk menunjukkan hal itu mereka mengubah cara belajarnya, tidak mengeluh serta rajin belajar dirumah untuk mendapatkan nilai yang maksimal.

\section{PENUTUP}

Berdasarkan hasil penelitian dan pembahasan melalui tahapan reduksi, penyajian data dan verifikasi dapat ditarik kesimpulan bahwa (1) Bentuk-bentuk alienasi yang terjadi pada siswa SMP Negeri 6 Makale yaitu ada empat yakni ketidakberdayaan (powerlessness), dua keterasingan diri (self-estrangement), ketiga tidak ada norma (normlessness) dan terisolasi secara sosial (social isolation). (2) Dampak alienasi pada siswa di SMP Negeri 6 Makale yakni berdampak negatif dan berdampak positif. Adapun dampak negatifnya yaitu: (a) siswa merasa tertekan dalam belajar, (b) siswa semangat belajarnya hilang, (c) siswa merasa dibatasi waktunya dalam hal bermain. Sedangkan dampak positifnya yaitu: siswa yang merasa teralienasi dari temannya justru termotivasi untuk lebih maju serta menunjukkan kepada temannya bahwa dia mampu bersaing dengan mereka.

\section{DAFTAR PUSTAKA}

Ashar, A., \& Awaru, A. O. T. (2017). Privilese Pada Siswa Di Sma Negeri 2 Sengkang Kabupaten Wajo. Jurnal Sosialisasi, 18-23.

Dinillah, N. (2018). Alienasi remaja akibat perceraian orang tua. UIN Sunan Ampel Surabaya.

Fahyuni, E. F., \& Istikomah, I. (2016). Psikologi Belajar \& Mengajar (kunci sukses guru dalam interaksi edukatif). Nizamia Learning Center.

Hascher, T., \& Hagenauer, G. (2010). Alienation from school. International Journal of Educational Research, 49(6), 220-232. https://doi.org/https://doi.org/10.1016/j.ijer.2011.03.002

Ja'far Shodiq, M. (2018). Analisis alienasi siswa dalam sekolah menurut Karl Marx; studi kasus SD Kemala Bhayangkari 9 Surabaya. UIN Sunan Ampel Surabaya.

Jones, P. (2010). Pengantar Teori-Teori Sosial: Dari Fungsionalisme hingga Postmodernisme. Yayasan Pustaka Obor Indonesia.

Kumari, F. (2016). Strategi Budaya dalam Filsafat Erich Fromm. Khazanah: Jurnal Studi Islam Dan Humaniora, 13(2), 185-208.

Marandika, D. F. (2018). Keterasingan Manusia menurut Karl Marx. TSAQAFAH, 14(2), 229-322.

Miles, M. B., \& Huberman, A. M. (1994). Qualitative data analysis: An expanded 
sourcebook. sage.

Moleong, L. J. (2014). Metodologi Penelitian Kualitatif, Ed. 33, Bandung: PT. Remaja Rosdakarya.

Nutbeam, D., Smith, C., Moore, L., \& Bauman, A. (1993). Warning! Schools can damage your health: alienation from school and its impact on health behaviour. Journal of Paediatrics and Child Health, 29, S25-S30.

SMAN, D. I., \& ISKANDAR, W. (2019). Alienasi Peran Intelektual Siswa Dalam Metode Pembelajaran Cooperative Learning.

Syukur, M. (2018). Dasar-Dasar Teori Sosiologi. PT. Rajagrafindo Persada.

Trusty, J., \& Dooley-Dickey, K. (1993). Alienation from school: An exploratory analysis of elementary and middle school students' perceptions. Journal of Research \& Development in Education.

Widodo, B. S. (2000). Slendro Pelog: Suatu Keterasingan di Dunia Anak. Harmonia: Journal of Arts Research and Education, 1(1). 